UDC 37.018.43:004]:616-036.21

DOI https://doi.org/10.31470/2415-3729-2021-13-152-166

\title{
The Role of Media Literacy in the Educational Field in the Conditions of a Pandemic
}

\section{Liudmyla Kukhar}

Doctor of Philosophy in Pedagogy (Ph.D), Associate Professor, Leading Specialist of the Department of the Bank of Test Tasks and Psychometric Analysis of the Ukrainian Center for Educational Quality Assessment,

Associate Professor of the Computer Engineering and Educational Measurements Department, National Pedagogical Dragomanov University

$\triangle$ 9, Pyrogova Str., Kyiv, Ukraine, 01601

E-mail: 1.o.kuhar@npu.edu.ua

ORSID http://orcid.org/0000-0003-0093-4877

Date of receipt of the article: April 15, 2021 Article accepted for publication: June 02, 2021

\section{Роль медіаграмотності в освітній галузі в умовах пандемії}

\section{Людмила Олександрівна Кухар}

кандидат педагогічних наук, доцент,

провідний фахівець відділу банка тестових завдань та психометричного

аналізу Українського центру оцінювання якості освіти, доцент кафедри комп'ютерної інженерії та освітніх вимірювань Національного педагогічного університету імені М.П. Драгоманова

$\triangle$ вул. Пирогова, 9, Київ, Украіна, 01601

Дата надходження статті: 15 квітня 2021 p. Стаття прийнята до друку: 02 червня 2021 p.

\section{Abstract}

The article analyzes the regulatory framework for the introduction of media education in the education system of Ukraine, 
identifies key competencies that modern youth should possess. The purpose of the article is to analyze the international experience of implementing media literacy curricula in the educational process. The following methods were used in the research: analysis of scientific and pedagogical literature, generalization, synthesis, formulation of conclusions. Results. The international experience of implementation of media literacy curricula in the educational process was studied. A scheme of a single information and educational space in the context of media education has been built, which will ensure the formation of a conscious and responsible consumer of media content. The authors have proposed the ways to organize collaboration with the class, together with the stages of training «Learning and behavior in the virtual classroom». The benefit of the study is that the possibilities of services and resources for collaboration remotely in a Covid-19 pandemic are analyzed, namely services for creating knowledge maps (Coggle, Cacoo), and bulletin boards (Padlet, Linoit), which allow you to organize collaboration and provide proper functionality. The article suggests the examples of tasks with the use of these resources are demonstrated. The authors state that for a long time media literacy has grown and evolved, but it is important to understand that recent advances and events, such as fake news, propaganda, bias, stereotypes and their widespread mechanisms in the fake media, have made media literacy even more relevant and necessary. They define that media literacy is a worldview; it forms a different view of everything we read, see and hear. Conclusions. The expected results of the formation of media competence and digital literacy as its component due to the integration of media education into compulsory disciplines, separate special courses, electives or clubs are formulated in the article as an important and necessary prerequisite for the formation of a modern information society. The authors conclude that the acquired knowledge, skills and abilities will allow people to analyse, critically evaluate and create messages of different genres and forms for different types of media, as well as to understand and analyse the complex processes of media functioning in society and their impact on their lives.

Key words: media education, media literacy, media competence, distance learning, knowledge maps, bulletin boards, joint work. 


\section{References}

1. Havrilova, L.H., Kukhar, L.O. \&Melnyk, O.M. (2021). Vykorystannia suchasnykh informatsiinykh tekhnolohii $v$ systemi pidvyshchennia kvalifikatsii vchyteliv [The use of modern information technologies in the system of teacher training]. In V.P. Serhiienka (Ed.). Kyiv: Vydavnytstvo NPU im. M.P. Drahomanova [in Ukrainian].

2. Naidonova, L. A. \& Sliusarevskyi, M. M. (Eds.) (2016). Kontseptsiia vprovadzhennia mediaosvity (nova redaktsiia) [The concept of introduction of media education in Ukraine (new edition)]. Retrieved from http://mediaosvita.org.ua/book/ kontseptsiya-vprovadzhennya-mediaosvity/ [in Ukrainian].

3. MON pidtrymuie initsiatyvu Prezydenta Ukrainy shchodo provedennia urokiv mediahramotnosti v shkolakh [The Ministry of Education and Science supports the initiative of the President of Ukraine to hold media literacy lessons in schools] (2021). Retrieved from https://www.kmu.gov.ua/news/mon-pidtrimuyeiniciativu-prezidenta-ukrayini-shchodo-provedennya-urokivmediagramotnosti-v-shkolah [in Ukrainian].

4. Reineck, D. \& Lublinski, J. (2015). Media and Information Literacy: A human rights-based approach in developing countries. DW Akademie. Published on Oct 16, 2015. URL: https://www. dw.com/en/media-and-information-literacy/a-18787411.

\section{Вступ}

Епоха цифрових технологій дала змогу будь-кому створювати медіа-контент. Ми не завжди знаємо, хто його створив, 3 якою метою і чи можна цим даним довіряти.

Ми стикаємось 3 великими обсягами даних з багатьох джерел: телевізор, соціальні мережі, відеоігри, реклама? радіо, газети та журнали, текстові повідомлення, меми, вірусні відео, тощо. Ці всі відомості були кимось створені та мали конкретну мету. Яку саме? Розуміння того, якою є мета і складає основу медіаграмотності. Медіаграмотність $є$ важливою навичкою в епоху цифрових технологій, що формується шляхом медіаосвіти у першу чергу в освітніх установах. 


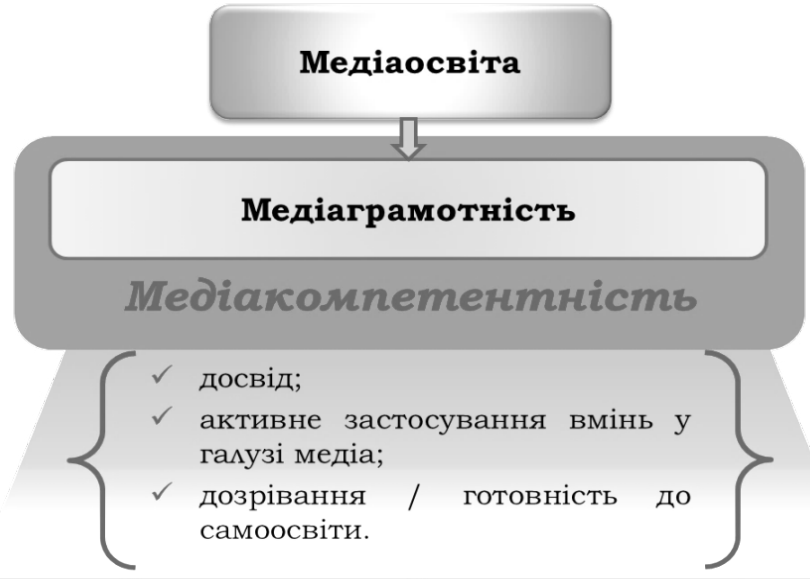

Компоненти медіакомпетентності

\section{Рис. 1. Взасмозв'язок між медіаграмотністю та медіакомпетентністю}

Ще в 2010 році було затверджено Концепцію впровадження медіаосвіти в Україні, яку було оновлено в 2016 році (Найдьонова \& Слюсаревський, 2016).

В Концепції було визначено вихідні положення, головну мету та завдання, основні терміни та поняття, принципи та пріоритетні напрямки розвитку, форми та етапи ії упровадження.

Наразі медіаосвіта і медіаграмотність викладаються в межах курсів «Основи медіаграмотності», «Сходинки до медіаграмоти», «Медіакультура», «Медіаосвіта» та інтегровано (в межах вивчення інших предметів).

Для учнів 5-9 класів розроблено типову освітню програму на виконання Державного стандарту базової загальної середньої освіти, в якій передбачено впровадження $з$ 2022/2023 навчального року курсу «Культура добросусідства», що містить основи медіаграмотності (МОН підтримує ініціативу..., 2021).

\section{Матеріал і методи досліджень}

У процесі дослідження було використано такі методи: аналіз науково-педагогічної літератури, узагальнення, синтез, формулювання висновків. 


\section{Результати та їх обговорення}

Meдіаграмотність - це здатність визначати різні типи засобів масової інформації та розуміти повідомлення, які вони надсилають.

Особистість нового покоління у світі цифрових технологій повинна володіти низкою компетенцій, що дасть їй змогу критично сприймати доступну інформацію (Рис. 2).

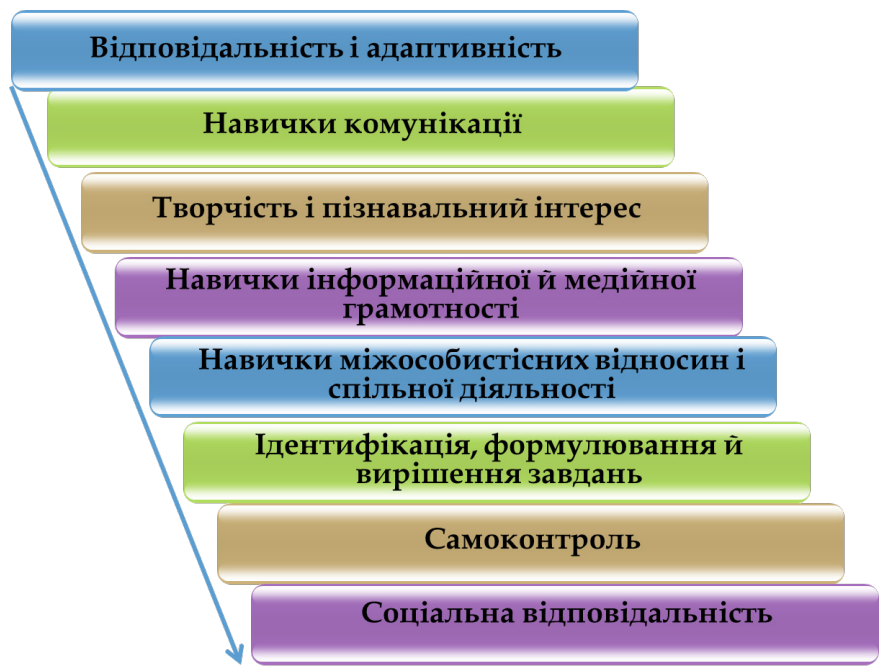

Рис. 2. Необхідні компетенції особистості нового покоління

Світовий досвід формування медіаграмотного суспільства полягає у тому, що упровадження окремої навчальної дисципліни для учнів 1-12 класів сприяє розвитку здатності учнів застосовувати власне критичне мислення у нових ситуаціях, створює підгрунтя для дискусій, роздумів, діалогів та не можливе без створення власних медіа-продуктів. До основних причин актуальності медіаосвіти відносять:

$\checkmark$ високий рівень споживання мас-медіа;

$\checkmark$ ідеологічну важливість медіа та їх вплив на свідомість;

$\checkmark$ швидке зростання обсягів медійних даних;

$\checkmark$ інтенсивність проникнення медіа в життя; 
$\checkmark$ зростання візуальної комунікації та інформатизації;

$\checkmark$ необхідність відповідати сучасним вимогам життя;

$\checkmark$ національні та міжнародні процеси «приватизації» даних.

Медіаосвіта включає вироблення технічних навичок роботи зі ЗМІ (засобами масової інформаціі) та IКТ (інформаційнокомунікаційними технологіями), критичного ставлення до інформації в них, і знання достовірних фактів про медіа $(\mathrm{MOH}$ підтримує ініціативу..., 2021). Серед них технічні навички, які передбачають можливість доступу та використання технічних пристроїв, що надають інформацію зі 3МI; навички декодування вмісту, що дають можливість аналізувати повідомлення, виділяти головне та самим створювати медіаконтент; знання фактів, як медіа змінюють відомості та формують громадську думку, яка їх роль у функціонуванні уряду, громадянського суспільства.

Науковці виділяються також сім вимірів медіаосвіти (МOH підтримує ініціативу..., 2021):

1. Доступ до засобів масової інформації та джерел інформації в них.

2. Використання медіа та інформації у повсякденному житті.

3. Оцінка медіа та інформації на предмет достовірності, точності та об' єктивності джерел.

4. Створення медіа ресурсів.

5. Участь у медіа, взаємодія з журналістами та редакторами, а також з іншими громадянами через старі та нові 3МI.

6. Знання того, як працюють медіа, інформаційні системи, організації.

7. Вимогливість до дотримання якості інформації та авторських прав у медіа.

Звичайно, формування медіаграмотної особистості - багатогранне завдання, яке відбувається в єдиному інформаційноосвітньому просторі із залученням тематичних дистанційних курсів, участі у мережевих спільнотах, роботою 3 електронними підручниками, підготовленими у межах низки міжнародних та всеукраїнських проектів 3 розвитку медіаосвіти, залученням педагогів та шкільних колективів до утворення сприятливого середовища для популяризації та формування свідомих споживачів інформації. 


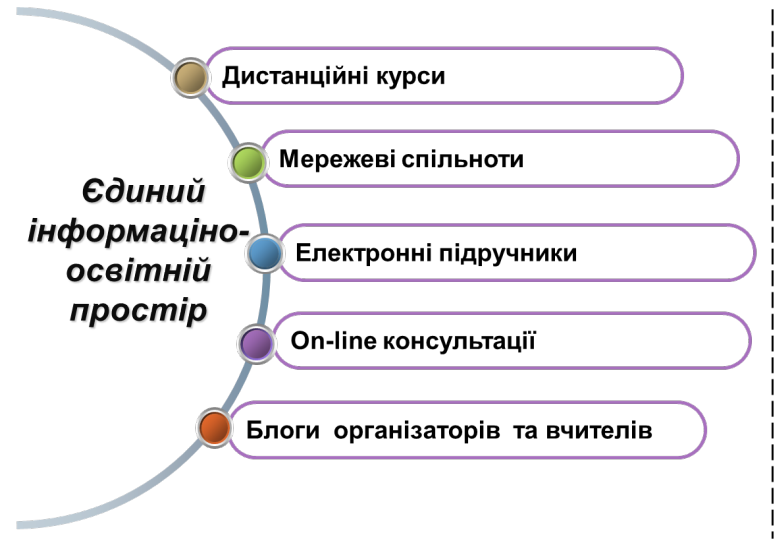

Електронна бібліотека

\section{Електронна} школа

Пілотна школа

\section{Рис. 3. Схема єдиного інформаційно-освітнього простору в}

\section{контексті медіаосвіти}

Проаналізуємо інструменти, які можуть використовуватися педагогом для проведення тренінгів чи виконання завдань $з$ формування медіаграмотності.

Так, під час пандемії Covid-19 та в умовах дистанційного навчання доречним та важливим $є$ проведення для усіх учасників освітнього процесу міні-тренінгу «Навчання та поведінка у віртуальному класі», який можна організувати засобами YouTube та Google Form.

Педагог готує коротке відео, у якому пояснює принципи роботи 3 обраною платформою дистанційного навчання (наприклад Google Classroom, Moodle), показує способи підключення до відео-конференції та пропонує учням сформулювати правила, яких необхідно дотримуватися у процесі роботи у віртуальному класі. 3 цією метою, під відео учитель може прикріпити посилання на Google Form, що містить перелік запитань, відповіді на які узагальнюються, обговорюються і вносяться у спільний документ (наприклад, можна створити спільно з учнями карту знань в середовищі Coggle 3 назвою «Правила поведінки і навчання у віртуальному класі»). 


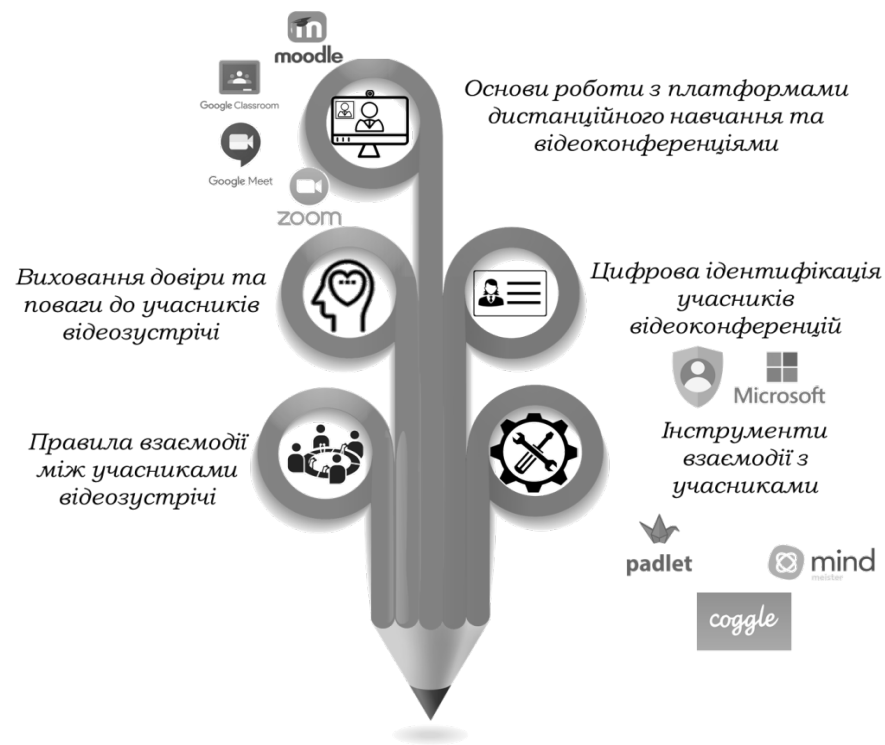

\section{Рис. 4. Етапи проведення тренінгу «Навчання та поведінка у віртуальному класі»}

Медіаграмотність включає постановку конкретних запитань та підтвердження своєї думки прикладами. Навчання дітей медіаграмотності у формі класичного уроку не дуже ефективне, краще його інтегрувати 3 повсякденною діяльність та життям. Так, з маленькими дітьми можна обговорювати речі, 3 якими вони знайомі, але на що можуть не звертати особливої уваги. Приклади включають рекламу зернових, упаковки продуктів та упаковки іграшок. Зі старшими дітьми ви можете за допомогою засобів масової інформації, які їм подобаються та які вони використовують обговорювати відео з YouTube , вірусні меми з Інтернету, оголошення для відеоігор та ін.

Основне, чому потрібно навчити дітей у процесі формування медіаграмотності - ставити правильні запитання. Наприклад:

- Хто це створив? Це була компанія? Це була особистість? (Якщо так, то хто?) Це був актор? Це був художник? Це було анонімне джерело? Чому ти так думаєш? 
- Чому їм це вдалося? Це було для того, щоб повідомити вам про щось, що сталося у світі (наприклад, новину)? Це було для того, щоб змінити свою думку чи поведінку (есе з думкою чи інструкція)? Це повинно було розсмішити тебе (смішний мем)? Це повинно було змусити вас купити щось (оголошення)? Чому ти так думаєш?

- Для кого це повідомлення? Це для дітей? Дорослих? Дівчат? Хлопців? Люди, які мають особливий інтерес? Чому ти так думаєш?

- Які методи використовуються, щоб зробити це повідомлення достовірним чи правдоподібним? Чи містить це повідомлення відомості з авторитетного джерела? Чи містить повідомлення цитати експерта? Чи є прямі докази того, що ці твердження достовірні? Чому ти так думаєш?

- Які деталі були висвітлені і чому? Чи узгоджена інформація 3 різних точок зору, чи вона містить лише погляди з одного боку? Вам потрібно більше інформації, щоб повністю зрозуміти повідомлення? Чому ти так думаєш?

- Які почуття та емоції викликало це повідомлення? Як ви думаєте, інші почувають себе так само? Чи всі сприймають це повідомлення однаково, чи певні люди мають інші відчуття? Чому ти так думаєш?

Оскільки діти стають все більш обізнаними про новини та поточні події та стають відкритими для них, можна застосувати кроки щодо медіаграмотності до радіо, телебачення та Інтернетінформації.

Цифрова грамотність $є$ частиною медіаграмотності та $є$ складовою цифрової грамотності, яка полягає у здатності ефективно знаходити, ідентифікувати, оцінювати та використовувати інформацію. Цифрова грамотність особливо стосується засобів масової інформації з Інтернету, смартфонів, відеоігор та інших нетрадиційних джерел. Подібно до того, як медіаграмотність включає здатність ідентифікувати медіа та його повідомлення та створювати медіа відповідально, цифрова грамотність включає як навички роботи з ресурсами, так і етичні зобов'язання.

Сучасні діти використовують величезну кількість цифрових засобів масової інформації для дослідження, спілкування, створення та навчання способами, яких раніше навіть не можна було собі уявити . Ці заходи дають як чудові можливості, так і мають 
потенційні «підводні камені»,що може призвести до кібербулінгу, цифрового обману та проблем безпеки. Ось чому цифрова грамотність $є$ надзвичайно важливою складовою медіаграмотності.

Можна виділити деякі ключові навички цифрової грамотності, які діти можуть засвоїти як удома так і в школі:

Ефективний пошук. Від вивчення шкільного предмету до перегляду найновішого музичного відео, діти повинні навчитися оцінювати якість, достовірність медіа та належним чином довіряти джерелу.

Захист своєї та чужої особистої інформації в Інтернеті. Маючи так багато способів обміну інформацією, діти повинні вивчити основи безпеки в Інтернеті, такі як створення надійних паролів, використання налаштувань конфіденційності та повага до конфіденційності своїх друзів .

Авторське право та правила циитування під час використання роботи інших людей. У світі, де все можна копіювати, вставляти і навіть вважати своїм, дуже важливо, щоб діти навчилися правильно посилатися на джерела.

Розуміння наслідків своєї діяльності в мережі. Те, що робить цифрові медіа такими доступними (можливість взаємодіi), також створює так звані сліди в Інтернеті. Діти повинні розуміти, що кожен раз, коли вони створюють профіль, публікують або коментують щось, вони створюють складений профіль, який потенційно можуть переглядати інші.

Повага ідей та думки один одного. Для того, щоб доступний нам віртуальний світ функціонував належним чином, ми всі повинні мати належний рівень цифрової грамотності та культури.

Тому під час занять на яких формується медіаграмотна особистість зручно використовувати програмні засоби та додатки, що дозволяють спільно працювати в реальному часі.

Розглянемо кілька популярних та зручних сервісів для спільної роботи.

Карти знань Coggle. Основна особливість сервісу (https:// coggle.it/) - простота роботи, зрозумілий інтерфейс, можливість додавати посилання на відео з Youtube. Учитель, створивши центральний об'єкт, може надати доступ до карти, в якій учні заповнюють різноманітні «гілки» за які вони відповідають. 


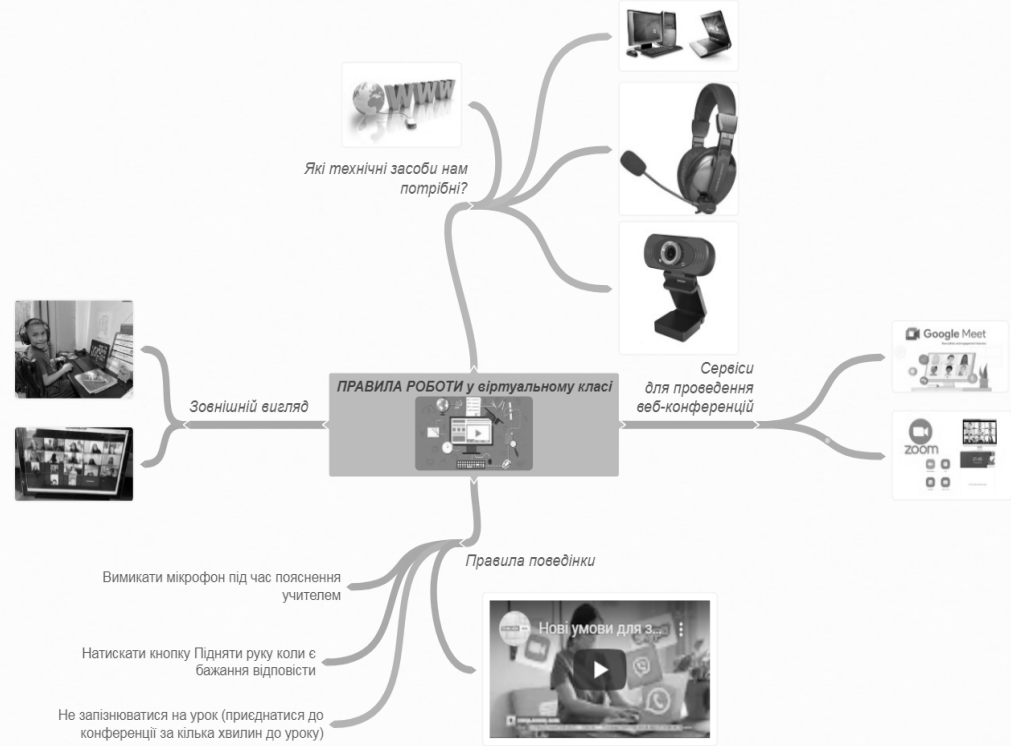

Рис. 5. Зразок карти знань, створеної учнями, спільно з учителем в Coggle

Альтернативою до використання карти знань Coggle можуть стати додатки Mind Meister, Draw.io, PersonalBrain, Cacoo.

Ще одним інструментом для спільної роботи є велика кількість віртуальних дошок оголошень.

Дошка оголошень Padlet (https://uk.padlet.com/), є зручною для роботи, $з$ нею можна працювати не лише в комп'ютері, а й з мобільного додатку (Гаврілова, Кухар \& Мельник, 2021).

Також на увагу заслуговує додаток Linoit, який дозволяє створювати полотна (canvas) та розміщувати на них стікери (stickers) із записами, зображеннями, відео, посиланнями на електронні ресурси, завданнями кожному учню/студенту; працювати колективно; використовувати на iPhone, iPad, Android; створювати власну групу та ділитися полотнами та стікерами з іншими користувачами; передивлятися створені іншими користувачами віртуальні дошки.

В мережі існує ще велика кількість віртуальних дошок: IDroo (https:// idroo.com/), Draw Chat (https://draw.chat/), Miro (https://miro.com/onlinewhiteboard/), Animaker (https://www.animaker.com/whiteboard) та інші. 


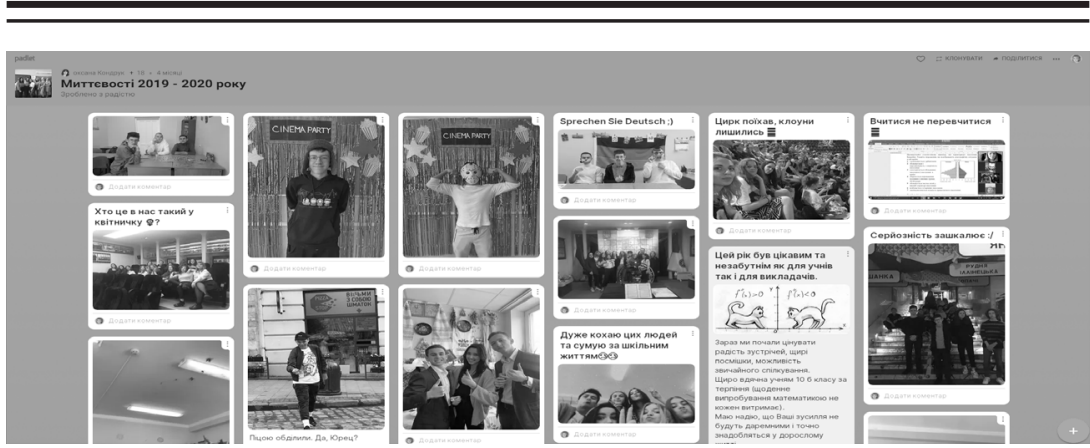

Рис. 6. Зразок дошки оголошень, створеної учнями, спільно 3 учителями в Padlet

До результатів, які можна очікувати внаслідок впровадження та засвоєння основ медіаграмотності у школі можна віднести:

$\checkmark$ Критичне мислення. Діти оцінюють засоби масової інформації, вирішують, чи мають зміст повідомлення, чому та чи інша інформація була включена до повідомлення, що не включено та які основні ідеї переслідувалися. Діти вчаться підтверджувати свою думку на прикладах, можуть самостійно приймати рішення щодо повідомлень на основі знань, які вони вже мають.

$\checkmark$ Розумне споживання медіа-продуктів та інформації. Медіаграмотність допомагає дітям навчитися визначати, чи $є$ щось достовірним. Це також допомагає їм визначити «переконливий намір» реклами та протистояти прийомам, які використовують маркетологи для продажу продукції.

$\checkmark$ Визначення точку зору. Кожен творець має свій задум. Визначення авторського бачення допомагає дітям оцінити різні точки зору. Це також допомагає оцінювати відомості в контексті того, що вони вже знають, або вважають, що знають.

$\checkmark$ Створення медіа відповідально. Визнання власної точки зору, говорить про те, що ви хочете сказати, як ви хочете це сказати, і розуміння того, що ваші повідомлення мають вплив - це ключ до ефективного спілкування.

$\checkmark$ Визначення ролі 3МІ в нашій культурі. Засоби масової інформації говорять нам про щось, формуючи наше розуміння світу і навіть змушуючи нас діяти чи думати певним чином.

$\checkmark$ Розуміння мети автора. Що автор хоче Вам донести шляхом своєї публікації? Чи це суто інформативне, чи намагається змінити 
вашу думку, чи знайомить вас з новими ідеями, про які ви ніколи не чули? Коли діти розуміють, який тип впливу на них чинять, вони можуть робити усвідомлений вибір.

\section{Висновки}

Вплив технологічного прогресу на створення та споживання медіа, безумовно значний. Тривалий час медіаграмотність зростала та еволюціонувала, однак важливо розуміти, що останні досягнення та події, такі як поява фейкових новин, пропаганда, упередженість, стереотипи, представництво та широкі механізми ïx поширення у фальшивих 3MI зробили медіаграмотність ще більш актуальною та необхідною. Медіаграмотність - це світогляд. Медіаграмотність формує інший погляд на все, що ми читаємо, бачимо та чуємо.

Тому формування у школярів та студентів основ медіаграмотності та цифрової грамотності, як іiі складової, шляхом інтеграції медіаосвіти в обов'язкові дисципліни, окремі спецкурси, факультативи або гуртки є важливою та необхідною передумовою становлення сучасного інформаційного суспільства.

Отримані знання, навички та уміння, дозволять людям аналізувати, критично оцінювати і створювати повідомлення різних жанрів і форм для різних типів медіа, а також розуміти й аналізувати складні процеси функціонування медіа в суспільстві, та їхній вплив на їх життя.

\section{Література}

1. Гаврілова Л.Г., Кухар Л.О., О.М. Мельник. Використання сучасних інформаційних технологій в системі підвищення кваліфікації вчителів: навч.-метод. посіб. / за ред. проф. В.П. Сергієнка. Київ: Видавництво НПУ ім. М.П. Драгоманова, 2021. 308 c.

2. Концепція впровадження медіаосвіти в Україні (нова редакція)/ за ред. Л. А. Найдьонової, М.М.Слюсаревського. Київ, 2016. 16 с. URL:: http://mediaosvita.org.ua/book/kontseptsiyavprovadzhennya-mediaosvity/

3. МОН підтримує ініціативу Президента України щодо проведення уроків медіаграмотності в школах. 2021. URL: https:// www.kmu.gov.ua/news/mon-pidtrimuye-iniciativu-prezidentaukrayini-shchodo-provedennya-urokiv-mediagramotnosti-v-shkolah 
4. Reineck D. Lublinski J. Media and Information Literacy: A human rights-based approach in developing countries. DW Akademie. Published on Oct 16, 2015. URL: https://www.dw.com/en/media-andinformation-literacy/a-18787411

\section{Кухар Л.О.}

\section{Роль медіаграмотності в освітній галузі в умовах пандемії}

\section{Анотація}

У статті зроблено аналіз нормативної бази впровадження медіаосвіти в систему освіти України, визначено ключові компетентності, якими повинна володіти сучасна молодь. Досліджено міжнародний досвід імплементації навчальних програм 3 медіаграмотності у освітній процес. Побудовано схему єдиного інформаційно-освітнього простору в контексті медіаосвіти, що забезпечить становлення свідомого та відповідального споживача медіа контенту. Запропоновано способи організації спільної роботи 3 класом: запропоновано етапи проведення тренінгу «Навчання та поведінка у віртуальному класі», проаналізовано можливості сервісів та ресурсів для спільної роботи у віддаленому режимі в умовах пандемії Covid-19, а саме виокремлено сервіси для створення карт знань (Coggle, Cacoo), та дошок оголошень (Padlet, Linoit), що дозволяють організувати спільну роботу та забезпечують належний функціонал. Продемонстровано зразки виконання завдань із використанням зазначених ресурсів. Окреслено очікувані результати сформованості медіакомпетентності та цифрової грамотності як її складової внаслідок інтеграції медіаосвіти в обов'язкові дисципліни, окремі спецкурси, факультативи або гуртки, що є важливою та необхідною передумовою становлення сучасного інформаційного суспільства.

Ключові слова: медіаосвіта, медіаграмотність, медіакомпетентність, дистанційне навчання, карти знань, дошки оголошень, спільна робота. 
Кухар Л.А.

\section{Роль медиаграмотности в сфере образования в условиях панде- мии}

\section{Аннотация}

В статье сделан анализ нормативной базы внедрения медиаобразования в систему образования Украины, определены ключевые компетентности, которыми должна обладать современная молодежь.

Исследован международный опыт имплементации учебных программ по медиаграмотности в образовательный процесс. Построена схема единого информационно-образовательного пространства в контексте медиаобразования, что обеспечит становление сознательного и ответственного потребителя медиа контента.

Предложены способы организации совместной работы с класcom:

- разработаны этапы проведения тренинга «Обучение и правила поведения в виртуальном классе»;

- проанализированы возможности сервисов и ресурсов для совместной работы в удаленном режиме в условиях пандемии Covid-19, а именно выделены сервисы для создания карт знаний (Coggle, Cacoo) и досок объявлений (Padlet, Linoit), позволяющие организовать совместную работу и обеспечивающие надлежащий функционал;

- продемонстрированы образцы выполнения задач с использованием указанных ресурсов.

Оперелены ожидаемые результаты сформированности медиакомпетентности и цифровой грамотности как ее составляющей вследствие интеграции медиаобразования в обязательные дисциплины, отдельные спецкурсы, факультативы или кружки что является важным и необходимым условием становления современного информационного общества.

Ключевые слова: медиаобразование, медиаграмотность, медиакомпетентность, дистанционное обучение, карты знаний, доски объявлений, совместная работа. 